\title{
NILAI EDUKATIF DALAM PEMBACAAN BURDAH (STUDI ATAS PROSESI PERNIKAHAN ETNIS ARAB DI GORONTALO)
}

\author{
Faradila Amri ${ }^{\mathrm{a}, 1, *}$, Muh. Arif ${ }^{\mathrm{b}, 2}$ \\ ${ }^{a}$ IAIN Sultan Amai, Jl. Gelatik, Gorontalo, 90234, Indonesia \\ ${ }^{b}$ IAIN Sultan Amai, Jl. Gelatik, Gorontalo, 90234, Indonesia \\ ${ }^{l}$ faradilaamri@yahoo.com*; ${ }^{2}$ muharif@iaingorontalo.ac.id;
}

ARTICLE INFO

Article history:

Received : 2020-08-24

Revised : 2020-09-21

Accepted : 2020-12-21

Keywords:

Educative Value

Reading Burdah

Marriage,
Kata kunci:

Nilai Edukatif

Pembacaan Burdah

Pernikahan

\section{ABSTRACT}

This article elaborated on the educational value of Burdah reading in Gorontalo and described the implementation of Burdah reading tradition in Gorontalo, where various activities were usually carried out, for example at assemblies or at the stages before wedding ceremony. In general, the indigenous people of Gorontalo, in the traditional stages before their wedding, only performed the Saronde dance after holding recitation. This was different from Arabian ethnic in Gorontalo. They preferred to read Burdah and Barzanji. The results showed that the reading of Burdah was one of the traditions carried out with a traditional pattern and was upheld by the people of Gorontalo, especially the Arab ethnic group. This was because that the Arabian ethnic people of Gorontalo made Burdah as a tradition that should not be abandoned in every ceremony, especially in wedding ceremonies, circumcision, and the Prophet's birthday. Likewise with other activities, for example when a family was suffering from a disease in the hope that they could get a cure. The educational values in reading Burdah included: first, the cultural value of Burdah tradition was implemented in the form of religious teaching through customary traditions; second, religious values in the tradition of Burdah reading contained religious teachings to strengthen faith and piety; third, the social value of the tradition of Burdah reading was in a form of religious teaching to familiarize each other with maintaining friendship, respecting and remaining united in Islamic brotherhood.

\section{ABSTRAK}

Artikel ini mengelaborasi bagaimana nilai edukatif pembacaan Burdah di Gorontalo dan mendiskripsikan bagaimana pelaksanaan tradisi Burdah di Gorontalo, biasanya dilakukan berbagai kegiatan, misalnya pada majelisan atau pada tahap menjelang nikah. Pada umumnya masyarakat asli Gorontalo dalam tahapan adat menjelang nikah mereka hanya melakukan tarian Saronde setelah mengadakan pengajian. Hal ini berbeda dengan masyarakat keturunan Arab di Gorontalo, mereka lebih memilih mengadakan pembacaan Burdah dan barzanji. Hasil penelitian menunjukkan bahwa pembacaan Burdah merupakan salah satu tradisi yang dilaksanakan dengan pola tradisional dan dijunjung tinggi oleh masyarakat Gorontalo terutama etnis Arab di Gorontalo. Hal ini dikarenakan masyarakat Gorontalo yang berketurunan Arab menjadikan Burdah sebagai suatu tradisi yang tidak boleh ditinggalkan dalam setiap upacara terutama dalam upacara pernikahan, sunatan, dan upacara maulidan. Begitupula dengan kegiatan lainnya misalnya ketika ada keluarga yang menderita penyakit dengan harapan agar dapat memperoleh kesembuhan. 
Sehubungan dengan berkembangnya Islam di Gorontalo, masyarakat Arab di Gorontalo yang menerima dan melaksanakannya secara tradisional. Burdah yang di dalamnya terdapat pembelajaran yang baik dan pesan-pesan moral. Burdahpun bersendikan syariat dan adat yang berpedoman pada kitabullah yakni Al-Qur'an menunjukkan bahwa Burdah memiliki nilai edukatif yang tertuang dalam pelaksanaannya secara tradisional meliputi nilai sosial, agama, dan budaya.

\section{Pendahuluan}

Setiap individu tidak dapat lepas dari budaya, karena hal itu merupakan kekhasan yang membedakan kelompok yang satu dengan kelompok yang lainnya (Fadhilla, 2013). Setiap individu memiliki aturan dan tatanan kehidupan serta norma dan tradisi yang sama dan bahkan berbeda dengan kelompok masyarakat lainnya (Hasanah, 2017). Adat istiadat merupakan kompleksitas norma atau aturan yang dijunjung tinggi oleh penganutnya sebagai tatanan dalam kehidupan (Botutihe \& Daulima, 2003). Adat kebiasan dipandang sebagai hukum, apabila kebiasaan tersebut dinilai memiliki sinergitas dengan ajaran Islam dan dapat diterima oleh semua pihak tanpa ada pertentangan dengan hal tersebut. Jika dalam adat istiadat terdapat hal-hal yang dapat mempengaruhi keyakinan, maka tradisi tersebut tidak dapat dibenarkan dalam Islam. Walaupun terdapat beberapa kebiasaan yang dapat diterima namun sering terjadi ketidak sesuaian dengan syara' (Miftahul, 2015).

Ragam tradisi suku Gorontalo meliputi pertama, pernikahan, penobatan dan penyambutan pejabat (moloopu), pemakaman, pengguntingan rambut, dan pembeatan. Kedua, tradisi berupa zikir kepada Allah (diikili), buruda, dana-dana dan zamrah. Ketiga, tradisi berkaitan dengan gerak atau olahraga tarian seperti langga, longgo. Keempat, tradisi yang berkaiatan dengan sastra berupa prosa maupun puisi (As'adi, 2020). Agama itu merupakan produk kebudayaan atau pengembangan dari aktivitas manusia sebagai makhluk pencipta kebudayaan (Natalia, Tarantang, \& Astiti, 2020).

Dalam suatu tatanan atau tradisi diatur bagaimana manusia berinteraksi dengan sesama manusia lainnya, atau suatu komunitas dengan lainnya, bagaimana bersikap dengan lingkungannya dan bagaimana manusia berperilaku terhadap alam. Hal tersebut berkembang menjadi suatu sistem yang mempunyai pola dan norma, dan juga mengatur sanksi dan ancaman terhadap pelanggaran dan perilaku menyimpang (Fajrie, 2016).

Adat ( العادة) atau 'Urf (العرف) yang berarti adat atau kebiasaan. Sebagaimana dikemukakan oleh Abdul Wahab Khallaf, bahwa Urf adalah sesuatu yang telah diketahui dikalangan masyarakat dan direalisasikan dalam kehidupannya, baik menyangkut perkataan, perbuatan atau sesuatu yang ditinggalkan. 'Urf sebagai bentuk dari kebiasaan atau tradisi yang melembaga dalam sistem budaya masyarakat (Rahman, 2012). Selain itu dapat dipahami bahwa tidak ada perbedaan antara al-'urf dan al-âdah (Abdul Wahhab Khallaf, 1994). `Urf terbentuk karena adanya saling memahami di kalangan mereka, sekalipun mereka berlainan stratifikasi sosial, yaitu kalangan masyarakat biasa dan masyarakat elite. Berbeda halnya dengan ijma, karena ijma muncul dari kalangan mujtahid secara khusus. Sedangkan orang awam tidak memiliki kapabilitas tentang hal itu (Sucipto, 2015). Nilai merupakan salah satu bentuk pemahaman yang dikategorikan sebagai sistem kepercayaan menghindari suatu tindakan atau mengenai sesuatu yang pantas atau tidak pantas dikerjakan (Oktaviyanti, Sutarto, \& Atmaja, 2016).

Berdasarkan uraian di atas dapat dipahami bahwa tradisi sebagai alat interaksi dalam sistem ideologi, sistem sosial, mencakup interaksi sosial masyarakat, sudah mentradisi sejak dahulu dan masih terpakai sampai saat ini. Hal ini membuktikan bahwa masyarakat selalu melestarikan tradisi yang telah ada. Salah satunya yaitu tradisi pembacaan Burdah. Burdah adalah salah satu karya cukup 
Vol. 16, No. 02, Desember 2020, p. 149-162

lama bertahan hingga sekarang ini. Pembacaannyapun sudah menjadi kebiasaan bangsa Arab sehingga menjadikan Burdah sebagai tradisi dalam kehidupan keseharian dan sistem sosialnya. Burdah tidak saja dilakukan sebagai ritual rutin pada saat menjelang salat lima waktu dan setiap malam Jumat. Namun juga sebagai wirid wajib dalam setiap upacara tertentu, misalnya pada perayaan maulid Nabi Muhammad saw., dan hajatan resepsi pernikahan (Adib, 2009).

Sebelum berkembangnya Sastra Arab secara luas, agama Islam telah hadir di tengahtengah masyarakat Arab, Islam berhasil menentukan arah perkembangan sastra Arab pada waktu itu. Keindahan Al-Qur'an, kebenaran agama Islam sekaligus perilaku mulia Nabi Muhammad saw., juga membuat kalangan sastrawan menulis syair mengenai Islam dan Nabi Muhammad saw. Beberapa sastrawan yang terkenal dalam membela agama dan nabinya yaitu Hassan bin Tsabit, Ka'ab bin Zuhayr, Hutai'ah. Mereka semua hidup pada masa awal permulaan Islam. Namun ada juga yang hidup pada zaman Mamluk yang puisinya dikenal berisi pujianpujian terhadap Nabi Muhammad saw., yaitu Al-Bushiri. Karya luar biasanya dirangkum dalam buku Qasidah Burdah dan telah diterjemahkan ke berbagai bahasa. Selain itu, Burdah adalah karya seringkali dicari oleh banyak orang. Sebagian salaf masih sering membacakan Burdah, terkadang masih dapat didengarkan syair-syair dalam Burdah ketika perayaan maulid Nabi dan perayaan Islam lainnya (Nihayah, 2015a).

Qasidah Burdah termasuk klasik karena dikategorikan memenuhi kaidah sastra serta sesuai dengan kaidah-kaidah syair seperti adanya emosi, imajinasi, gagasan, bentuk dan sangat memperhatikan keabsahan irama dan keluwesan irama. Qasidah ini menggunakan irama bahr basith sehingga terasa halus, lembut dan cocok untuk sya'ir madh. Apabila dilihat dari segi irama, qasidah ini menggunakan qafiah yang berawikan mim karena ternyata huruf mim merupakan huruf yang ringan, mudah diucapkan dan lembut didengar. Corak sastra seperti inilah yang diterima di masyarakat sehingga corak sastra ini bersifat abadi dan menarik bagi pendengarnya (Nabilah, 2018).
Qasidah Burdah adalah salah satu karya paling populer dalam khazanah sastra Islam, isinya sajak-sajak pujian kepada Nabi Muhammad saw., pesan moral, nilai-nilai spiritual dan semangat perjuangan. Hingga kini masih sering dibacakan di berbagai pesantren salaf dan pada peringatan maulid nabi (Rosalinda, 2013).

Qasidah Burdah merupakan al-mada'ih an-nabawiyah yang dikembangkan para sufi sebagai cara untuk mengungkapkan perasaan cinta yang mendalam. Qasidah ini terdiri atas 160 bait (sajak), ditulis dengan gaya bahasa (uslub) yang menarik, sehingga enak didengar. Qasidah Burdah tersebut berisi panduan ringkas mengenai kehidupan Nabi Muhammad saw., cinta kasih, pengendalian hawa nafsu, doa, pujian terhadap Al-Qur'an, Isra Mi'raj, jihad dan tawassul. Dengan menguraikan sejarah hidup Nabi secara puitis, Al-Bushiri tidak hanya menanamkan kecintaan kepada Nabiullah Muhammad, tetapi beliau juga mengajarkan sastra, sejarah Islam, serta nilai-nilai moral kepada kaum muslimin. Olehnya itu qasidah Burdah senantiasa dibacakan di beberapa pesantren Salafiyah. Qasidah Burdah juga diajarkan dua kali sepekan yakni hari Kamis dan Jumat di Universitas Al-Azhar Kairo (Faqieh, 2010).

Qasidah Burdah awalnya diciptakan oleh Imam Al-Bushiri saat menderita sakit yang cukup parah dan berkepanjangan. Pada masamasa sulit menjalani penyakit lumpuh yang dideritanya, imam Al-Bushiri menggubah qasidah yang ditujukan kepada Nabi Muhammad saw., dengan mengharap ridha Allah swt., agar disembuhkan penyakit yang ia derita. Hingga pada suatu malam, setelah membacakan qasidah Burdah yang dibuatnya, Imam Al-Bushiri tertidur. Kemudian ia bermimpi bertemu dengan Nabi Muhammad saw., dan ia diberi surban. Saat terbangun dari tidurnya, Imam Al-Bushiri merasakan keajaiban yang tak terduga, karena penyakit yang diderita sejak sekian lama tiba-tiba sembuh. Keajaiban yang dialami oleh Imam al Bushiri menjadi alasan utama terhadap penamaan qashidah Burdah tersebut (Nihaya, 2014).

Burdah adalah sebuah syair yang memiliki nilai sastra yang indah. Sastra dan agama juga tidak dapat dipisahkan, hal ini menunjukkan bagaimana Allah swt., menyampaikan ajaran- 
Nya kepada manusia melalui Rasul-Nya dalam firman-Nya yang berbahasa Arab. Kemudian Rasul menyampaikan dengan menggunakan bahasa yang indah dengan gaya sastra luar biasa (Muzakki, 2006). Hal ini dapat dipahami bahwa sastra juga merupakan suatu alat yang sangat baik untuk menyampaikan ajaran agama. Selain manfaat di atas sastra juga dapat dipakai menjadi alat pendidikan.

Pada pelaksanaan menjelang nikah, ritual ini diadakan terlebih dahulu pada malam pacar/inai. Pada masyarakat Bugis dikenal dengan istilah Mappaci, dengan menggunakan daun pacar (lawsania alba) atau pacci yang dioleskan kepada pengantin. Adapun yang mengoleskan daun pacar adalah keluarga terdekat, biasanya diawali dari salah seorang dari orang tuanya (ayah atau ibunya) kemudian disusul dari paman, tante dan saudara, sepupu dan kerabat lainnya. yang jumlahnya harus ganjil. Lain halnya dengan etnis Arab, Pacar adalah acara khusus bagi pengantin perempuan yang diawali dengan pembacaan qasidah Burdah kemudian diselingi dengan hiburan khas Arab dan diiringi tarian-tarian Arab berupa zamrah oleh teman-teman maupun kerabat dari calon mempelai wanita. Acara diakhiri dengan pengolesan pacar (henna) oleh para sesepuh kepada calon mempelai wanita sebagai tanda doa restu.

Qasidah Burdah sudah populer di Indonesia khususnya pada masyarakat santri dan nahdiyyin. Terdapat beberapa qasidah Burdah terjemahan dalam bahasa Indonesia, salah satu dianataranya adalah buku yang berjudul "Sajak-Sajak Burdah" oleh Dr. Muhammad Tholchah Mansur, judul yang lain oleh K.H M Sarwani Abdan dengan judul "Qasidah Burdah Imam al-Bushiry", pernah diterjemahkan ke dalam bahasa Jawa K.H Biysri Mustafa dengan judul "Tiryaqul alAghyar fi Tarjamati Burdat al-Mukhta (Mansoer, 2006).

Terdapat beberapa kitab yang pada dasarnya merupakan karya sastra berbentuk puisi, prosa dan syair. Diantara yang populer di Indonesia adalah Qasidah al-Burdah oleh Imam Al-Bushiri (Nihayah, 2015b). Burdah tergolong unik dan istimewa karena: Pertama syair Burdah dianggap sebagai pelopor yang menghidupkan kembali penggubahan syair- syair pepujian terhadap Nabi Muhammad (almada'ih an-nabawiyyah). Ia adalah syair pepujian terhadap Nabi Muhammad yang paling awal pasca terjadinya masa kekosongan yang sangat panjang, Kedua syair Burdah dinilai sangat tinggi kualitas sastra dan pesan-pesan yang dimuatnya. Ketiga kandungan syair ini terhitung cukup lengkap. Ia tidak saja menyajikan sejarah dan pepujian rasul, namun juga mengujarkan beragam ajaran tasawuf dan moral yang cukup mendalam. Keempat selain sebagai Wiridan rutin biasanya setiap malam Jumat syair Burdah juga dibaca pada berbagai upacara tertentu. Di saat ada hajatan tertentu, misalnya hendak menempati rumah baru, atau ketika tradisi situasi krisis dan bencana seperti serangan wabah penyakit, syair ini dibaca secara berjamaah sebagai bagian dari ritual untuk mendatangkan kesembuhan dan mengusir malapetaka. Tradisi magisme seperti ini sudah muncul sejak syair ini digubah dan terus bertahan hingga saat ini (Adib, 2009). Kelima Burdah memiliki nilai-nilai silaturahmi dan nilai cinta kepada Nabi Muhammad saw. (Ramin, 2018).

Burdah di Gorontalo sangat menarik karena tidak hanya diadakan untuk pernikahan akan tetapi pada hajatan lainnya, misalnya maulid Nabi, arisan ibu-ibu rumah tangga, dll. Burdah paling sering diadakan di Gorontalo dengan menggunakan alat rebana yang besar, biasanya dilakukan secara bersamaan. Khususnya masyarakat Gorontalo yang berketurunan Arab, mereka mengadakan burudah pada acara pernikahan.

\section{Tinjauan Pustaka}

Berdasarkan hasil bacaan penulis tentang Burdah telah ditulis oleh penulis sebelumnya dengan berbagai perspektif yaitu: Pemaknaan Tradisi Burdah Desa Jaddung Pragaan Sumenep Madura Jawa Timur (Perspektif Hermeneutika Gadamer), (Ramin, 2018). Tradisi Baca Burdah dan Pengalaman Keagamaan Masyarakat Desa Setiris Muaro Jambi, (Rosalinda, 2013). Konsep Seni Qasidah Burdah Imam Al-Bushiri sebagai Alternatif Menumbuhkan Kesehatan Mental (Nihaya, 2014). Qasidah Burdah Imam AlBushiri; Model Alternatif Dakwah Pesantren (Nihayah, 2015b). Qasidah Burdah: Syair Cinta untuk Sang Rasul (Nabilah, 2018). Sajak-sajak Burdah Imam Muhammad Al- 
Vol. 16, No. 02, Desember 2020, p. 149-162

Bushiri: (Mansoer, 2006). Nilai-Nilai Spiritual Sufistik Qashidah Burdah dalam Meningkatkan Religiusitas (Studi Fenomena di Pondok Pesantren Darussalam Martapura) (Mahlan, 2015). Akhlak dalam Kasidah Burdah (Studi Pembacaan Burdah di Pondok Pesantren Nurul Jadid Paiton Probolonggo), (Fitriyah, 2016). Tema dan Amanat dalam Qashidah Burdah Karya Imam al-Bushairi yang Mengandung at-Thibaq (Tinjauan Ilmu Badi') (Fahriah, 2012). Studi Kritis terhadap Pemikiran al-Busiri dalam Qasidah Burdah (Bakari, 2014). Pemaknaan Teks Syair Qashidah Burdah Karya Imam Syarifuddin Abu Abdillah Muhammad Bushiry (Kajian Semiotika Michael Riffaterre) (Arifin, 2018). Burdah: Antara Qasidah, Mistis dan Sejarah (Adib, 2009).

Selanjutnya penulis berupaya mengkaji kembali tentang Burdah yakni: Nilai Edukatif dalam Pembacaan Burdah Studi atas Prosesi Pernikahan Etnis Arab di Gorontalo. Kajian ini menarik karena masyarakat Gorontalo khususnya yang berketurunan Arab menjadikan sebuah tradisi yang harus dilakukan pada saat pernikahan dilaksanakan dengan melalui tahapan: Pertama, membaca dengan suara berirama tradisional dengan menggunakan rebana; Kedua, pembaca harus menguasai bahasa Arab dengan baik serta tajwidnya, bagian penting dalam membaca teks Burdah; Ketiga, Duduk dengan sopan berbentuk huruf $U$ di depannya ada sang pengantin, kemudian membaca teks Burdah dengan bergiliran; Keempat, Teks yang dibacakan mempunyai nilai-nilai pendidikan Islam seperti nilai sosial, agama dan budaya; Kelima, bagian pembacaan Burdah semua mencangkup keagamaan, di dalam Burdahpun terdapat kisah Isra Mi'raj dan lain sebagaianya; Keenam, pada bagian pembacaan Burdah ini terdapat nilai sosial karena semua yang hadir saling menjaga silaturahmi yang baik dengan tujuan yang sama; Ketujuh, pada bagian pembacaan Burdah ini terlihat bahwa budaya masyarakat Arab tidak akan hilang meski tidak pada Timur Tengah itu sendiri.

Selanjutnya dalam prosesi pembacaan Burdah terdapat beberapa hal yang perlu dipersiapkan termasuk rumah mempelai karena rumah merupakan sentra keluarga sakinah yang melaksanakan Burdah secara tradisional; ruang pembacaan, pada pelaksaan
Burdah untuk yang menikah dihias dengan bagus dan berlatar belakang bunga ada tempat duduknya untuk mempelai wanita; Rebana, Dumbuk dan Krinci adalah alat musik yang pakai ketika membaca teks-teks Burdah; Gelas air putih untuk diminum pembaca; Bunga rampe/ parfum Arab akan digunakan oleh pengantin pada saat pembacaan akan diberikan kepada para pembaca yang hadir di tempat; Polutube tempat bakar dupa/kemenyan; Kemenyan/dupa digunakan sang pembaca pada saat membaca teks-teks Burdah sebagai pengharum ruangan; Bara api dipakai selama pembacaan berlangsung; Mike dipakai sebagai pengeras suara agar teks-teks yang dibacakan terdengar oleh para tamu dan para pembaca lainnya.

\section{Metodologi Penelitian}

Kegiatan pengumpulan data melalui prosedur penelitian yakni pengamatan dan wawancara (Fattaah, 2018), suatu proses tanya jawab yang mempertemukan antara peneliti dan narasumber yang akan diambil datanya. Jenis penelitian ini merupakan penelitian deskriptif kualitatif etnografis. Penelitian kualitatif merupakan penelitian yang memanfaatkan cara-cara penafsiran dengan menyajikannya dalam bentuk deskripsi. Spradley menyatakan bahwa etnografi merupakan pekerjaan mendiskripsikan suatu kebudayaan. Tujuan utama penelitian etnografi ini adalah memahami suatu pandangan hidup dari sudut pandang penduduk asli (Fitriyah, 2016).

\section{Hasil dan Diskusi}

Sebelum diuraikan lebih lanjut tentang nilaiedukatif dalam tradisi Burdah, maka dapat dilihat kerangka pembahasan sebagai berikut:

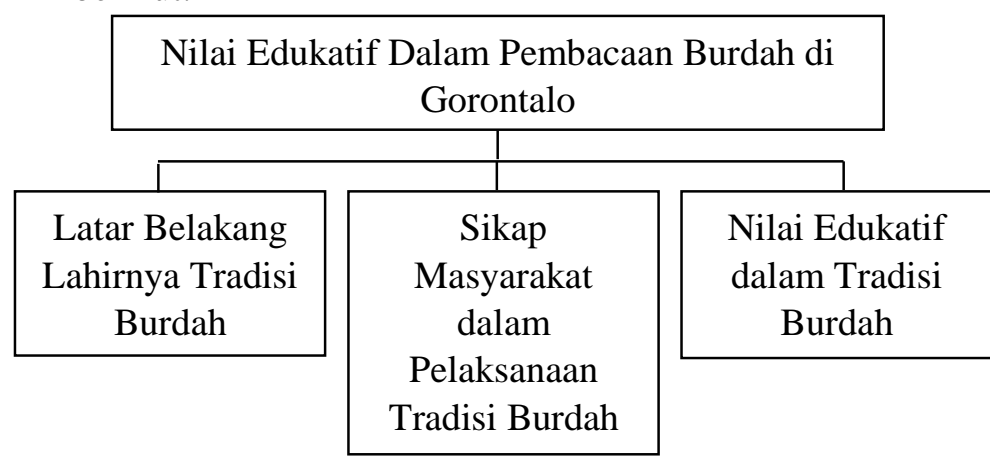

Gambar 1. Ruang Lingkup Pembahasan Hasil Penelitian 


\section{Burdah dalam Pelaksanaan Tradisional dan Nasional}

Tradisi pembacaan Burdah bagi masyarakat pada umumnya di seluruh Indonesia dapat dilakukan secara tradisional, dimulai dari rumah ke rumah, majelis, dan pesantren. Pembacaan Burdah dilaksanakan di berbagai daerah dengan pelaksanaan yang berlainan, misal, mereka membaca karena ingin bersalawat kepada Nabi dengan teks yang berbeda, membacanya agar memperoleh berkah dan syafaat serta menjadikannya sebagai pembelajaran yang dapat ditekuni melalui arti dan pemahaman yang didapatkan.

Dasar pendidikan pondok pesantren adalah untuk melaksanakan dakwah Islamiyah melalui jalur pendidikan diniyah salafiah, yang diselenggarakan dengan pengajian kitab kuning. Dengan berpegang kepada prinsip "mempertahankan tradisi lama yang baik dan menerima tradisi baru yang dianggap lebih baik (Mustajab, 2015).

Pada awalnya Burdah hanya sebagai nama saja yang kemudian di dalamnya mereka membacakan bacaan barzanji, mengapa demikian dikarenakan mereka menginginkan adanya asyraka yang apabila dibacakan semua orang akan berdiri dan akan melagukannya, disaat itu calon pengantinpun akan keluar dari kamarnya, dan akan disambut dengan asyraka. Namun ada juga yang ingin memakai Burdah, di awal pembacaan beberapa salawat Burdah akan dibacakan kemudian di pertengahan akan membacakan asyraka, hal demikian dilakukan karena semua tergantung dari yang mempunyai acara (tuan rumah) (NA, 2019).

Pada pelaksanaan tradisional di berbagai tempat di Gorontalo, memang memiliki perbedaan masing-masing pada masyarakat Arab identik dengan ornamen yang sudah menjadi budaya dan tradisi mereka, namun di lain tempat seperti pada masyarakat Gorontalo asli tidak memperlihatkan keidentikan mereka pada saat pelaksanaan mulai berlangsung. Bagi masyarakat yang menerima mereka semua pasti melaksanakannya, demi terjalinnya silaturahmi dan rasa persaudaraan antar umat maka secara sadar mereka telah membangun suatu hubungan yang baik (hablun minannâs).

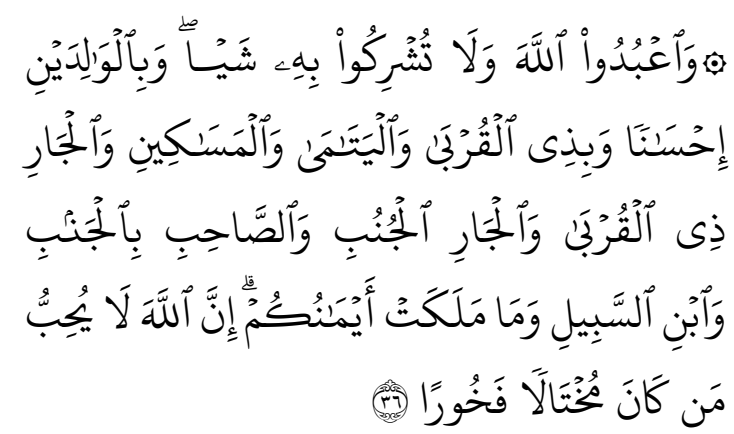

Artinya: Sembahlah Allah dan janganlah kamu mempersekutukan-Nya dengan sesuatupun. Dan berbuat baiklah kepada dua orang ibu-bapa, karib-kerabat, anak-anak yatim, orang-orang miskin, tetangga yang dekat dan tetangga yang jauh, dan teman sejawat, ibnu sabil dan hamba sahayamu. Sesungguhnya Allah tidak menyukai orangorang yang sombong dan membanggabanggakan diri. (Q.S An-Nisa [4]:36)

Salah satu kewajiban muslimah adalah menjalin hubungan manusia antara satu dengan yang lainnya, saling membutuhkan, sudah seharusnya manusia dapat menjalin hubungan yang sebaik-baiknya, sebagaimana dijelaskan pada ayat di atas (Yani, 2006).

Masyarakat yang menerima sudah pasti akan melaksanakannya, seperti yang telah peneliti temui calon mempelai wanita yang akan melaksanakan Burdah, dia menerima tradisi ini yang sudah ada sejak dahulu, dan menjalankannya dengan baik. Calon mempelaipun akan menyediakan berbagai macam ornamen yang selalu disediakan di dalam pelaksanaan Burdah diantaranya adalah bunga rampe sebagai wewangian untuk diberikan kepada para tamu disaat pengantin akan keluar dari kamarnya, jika tidak ada bunga rampe, parfum khas Arab dibuat sebagai penggantinya, kemudian dupa dan bara yang akan diberi kemenyan oleh pembaca Burdah, kemudian alat-alat musik klasik yang akan digunakan pada saat salawat akan dinyanyikan (ZAB, 2019).

Pada ornamen-ornamen yang sering terihat pada pelaksanaan Burdah sering ditemukan kemenyan atau dupa. Dupa dipakai bukan sebagai hal kesyirikan melainkan sebagai pengharum ruangan saja. Di Masjid Nabawi atau Masjidil Haram, kemenyan kerap hadir di beberapa acara seperti acara wisuda Tahfidz, acara penyucian atau pembersihan Ka'bah, dan lain sebagainya. Hal itu untuk 
mengharumkan udara dan menyenangkan jiwa pada peziarah (Saputra, 2017).

Karena menurut salah satu hadits Nabi, para malaikat itu suka bau-bau yang wangi dan membenci bau-bau busuk. Adapun Hadis yang berkaitan dengan kemenyan yaitu hadis shahih riwayat Imam Muslim berikut ini :

"Dari Nafi', ia berkata, "Apabila Ibnu Umar mengukup mayat (membakar kemenyan), maka beliau mengukupnya dengan kayu gaharu yang tidak dihaluskan, dan dengan kapur barus yang dicampurkan dengan kapur barus. Kemudian beliau berkata, "Beginilah cara Rasulullah saw., ketika mengukup jenazah (membakar kemenyan untuk mayat)". (HR. Muslim)

Dalam hal-hal identik yang lain ditemukan pula pakaian mereka yang kebanyakan serba hitam, panjang hingga menutupi aurat, pakaian itu biasa disebut Abaya. Abaya adalah pakaian khas orang timur terkhusus perempuan, abaya dikenakan karena simpel, tidak ribet, dan menutupi aurat warnanyapun tidak menyolok, dan lebih memperlihatkan kesederhanaan (NUA, 2019). Pada pembacaan Burdah terdapat pemahaman pro dan kontra sebagaian berpendapat bahwa tradisi seperti ini tidak ada di zaman nabi, tetapi pada dasarnya Burdah itu telah ada di zaman Nabi Muhammad saw., perbedaan pendapat (NA, 2019).

Corak kaum tradisional itu tidak lepas pula dari strategi dakwah yang diterapkan oleh penyebar Islam mula-mula di Indonesia, yakni para ulama Walisongo. Dengan pertimbangan keadaan masyarakat Indonesia saat itu yang sebagian besar petani yang tinggal di daerah pedesaan dan tingkat pendidikannya sangat rendah, maka pola penyebaran Islampun harus disesuaikan dengan kemampuan pemahaman masyarakat, sehingga materi dakwah pada waktu itu lebih diarahkan pada peningkatan keyakinan bersifat pemujaan secara ritual (Sholikhin, 2010).

Demikian Burdah hanya dilaksanakan secara tradisional saja, tidak ada pelaksanaan secara nasional, meski Burdah sudah dilaksanakan secara turun temurun namun tidak ada pelaksanaan secara nasional. Karena ini telah menjadi tradisi pada masyarakat luas, sehingga pelaksanaannya bersifat tradisi saja.

\section{Nilai Edukatif dalam Pembacaan Burdah}

Pendidikan Islam yang berakar pada budaya yaitu pendidikan Islam yang tidak meninggalkan akar-akar sejarah, baik sejarah kemanusiaan pada umumnya maupun sejarah kebudayaan suatu bangsa, kelompok etnis, atau suatu masyarakat tertentu. Maka dari itu nilai pendidikan Islam yang berakar pada budaya diharapkan dapat membentuk manusia yang mempunyai kepribadian, harga diri, percaya diri dan membangun peradaban berdasarkan budaya sendiri yang akan menjadi warisan monumental dari nenek moyangnya bukan budaya bangsa lain. Pendidikan Islam berbasis pada nilai budaya lokal berpotensi untuk membentuk karakter jati diri bangsa dalam penguatan kebangsaan dan nasionalisme (Zubaedi, 2012).

Nilai ialah sesuatu yang berbentuk abstrak, yang bernilai mensifati dan disifatkan terhadap sesuatu hal yang ciri-cirinya dapat dilihat dari prilaku seseorang, yang memiliki hubungan yang berkaitan dengan fakta, tindakan, norma, moral, dan keyakinan. Nilai ialah sesuatu yang berbentuk abstrak, yang bernilai mensifati dan disifatkan terhadap sesuatu hal yang ciri-cirinya dapat dilihat dari perilaku seseorang, yang memiliki hubungan yang berkaitan dengan fakta, tindakan, norma, moral, dan keyakinan (Imelda, 2017). Nilai dapat diartikan sebagai suatu tipe kepercayaan yang menjadi dasar bagi seseorang maupun sekelompok masyarakat, dijadikan pijakan dalam tindakannya, dan sudah melekat pada suatu sistem kepercayaan yang berhubungan dengan manusia yang meyakininya (Aini, 2019). Nilai artinya sifat-sifat (hal-hal) yang penting atau berguna bagi kemanusiaan. Maksudnya kualitas yang memang membangkitkan respon penghargaan (Tantowi, 2009).

Nilai edukatif adalah suatu hal yang melekat pada pendidikan Islam yang digunakan sebagai dasar manusia untuk mencapai tujuan hidup manusia yaitu mengabdi pada Allah swt. Nilai-nilai tersebut perlu ditanamkan pada anak sejak kecil, karena pada waktu itu adalah masa yang tepat untuk menanamkan kebiasaan yang baik padanya. Jadi, nilai dalam pendidikan Islam adalah sesuatu yang bermanfaat bagi manusia setelah menjalani proses yang dilakukan 
secara sadar dan sengaja sehingga perilaku seseorang atau masyarakat berubah dari keadaan tertentu ke suatu keadaan yang lebih baik.

\section{a. Nilai Sosial}

Nilai sosial adalah sesuatu yang menjadi ukuran dan penilaian pantas tidaknya suatu sikap yang ditujukan dalam kehidupan bermasyarakat. Nilai ini memperlihatkan sejauh mana hubungan seorang individu dengan individu lainnya terjalin sebagai anggota masyarakat. Nilai sosial sangat nyata dalam aktivitas bermasyarakat. Nilai sosial tersebut dapat berupa nilai gotong royong, ikut terlibat dalam kegiatan musyawarah, kepatuhan, kesetiaan, dan lain sebagainya. (Aisah, 2017).

Berbicara tentang norma berarti menyinggung secara langsung petunjuk perilaku atau patokan perilaku yang dibenarkan dan pantas dilakukan dalam menjalin interaksi sosial dalam suatu kelompok masyarakat tertentu. Karakteristik dari norma sosial adalah umumnya tidak tertulis, hasil kesepakatan bersama, ditaati bersama bagi pelanggar diberikan sanksi, mengalami perubahan. Norma sosial dapat diklasifikasi: Pertama, berdasarkan daya ikat, seperti cara (usage), kebiasaan (folkways), tata kelakuan (mores), adat istiadat (costum), Kedua berdasarkan aspek-aspeknya, seperti (norma agama, norma kesusilaan, norma kesopanan, norma kebiasaan dan norma hukum), Ketiga berdasarkan resmi dan tidak resmi yaitu norma yang tidak resmi (non formal), norma resmi (formal) (Darwis \& Mas'ud, 2017).

Nilai sosial yang terdapat pada pelaksanaan Burdah terlihat jelas, ketika ini sudah menjadi sebuah budaya yang melekat terhadap individu atau kelompok masyarakat tertentu, pasti disitu akan ditemukan nilainilai sosial, terutama diantar kelompok majelis.

Mempertahankan tali persaudaraan, tali silaturahmi dapat memperpanjang umur. Sebagaimana dalam firman Allah swt.,

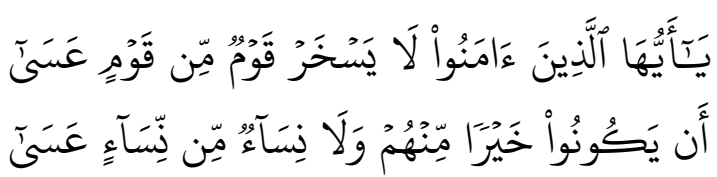

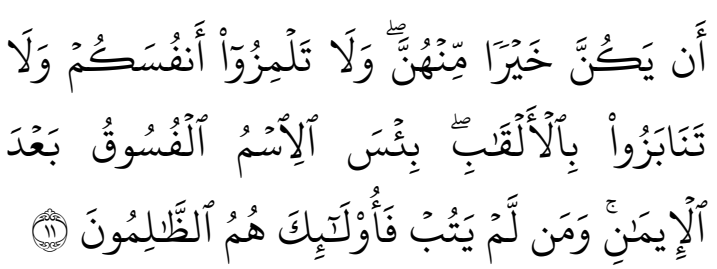

Artinya: Hai orang-orang yang beriman, janganlah sekumpulan orang laki-laki merendahkan kumpulan yang lain, boleh jadi yang ditertawakan itu lebih baik dari mereka. Dan jangan pula sekumpulan perempuan merendahkan kumpulan lainnya, boleh jadi yang direndahkan itu lebih baik. Dan janganlah suka mencela dirimu sendiri dan jangan memanggil dengan gelaran yang mengandung ejekan. Seburuk-buruk panggilan adalah (panggilan) yang buruk sesudah iman dan barangsiapa yang tidak bertobat, maka mereka itulah orang-orang yang zalim (Q.S Al-Hujurat [49]:11)

Ini juga merupakan hak-hak diantara sesama kaum mukminin, yaitu agar "Janganlah suatu kaum mengolok-olok kaum yang lain" dengan perkataan, ucapan, maupun perbuatan yang menunjukkan sikap menghina sesama saudara muslim, karena hal itu haram dan tidak diperbolehkan (As-Sa'di, 2012).

Berdasarkan ayat di atas yang menegaskan bahwa tidak boleh menghina suatu kaum serta memperolok-olokkannya.

\section{b. Nilai Agama}

Terdapat beberapa macam nilai-nilai agama mendasar yang harus ditanamkan pada seorang anak dan kegiatan menanamkan nilainilai pendidikan inilah yang sesungguhnya menjadi inti pendidikan agama. Di antara nilai-nilai yang sangat mendasar itu, ialah Iman, Islam, Ihsan, Taqwa, Ikhlas, Tawakkal, Syukur (Djamal, 2017). Manusia tidak akan mengalami ketidak nyamanan, ketidak harmonisan, ketidak tentraman, ataupun mengalami permasalahan dalam hidupnya, jika dalam menjalin hubungan-hubungan tersebut terjadi ketimpangan atau tidak mengikuti aturan yang telah ditetapkan oleh Allah swt (As-Sa'di, 2012). Nilai keagamaan mengenai penghargaan tinggi yang diberikan oleh warga masyarakat pada beberapa masalah pokok dalam kehidupan keagamaan yang bersifat suci sehingga menjadikan pedoman bagi tingkah laku keagamaan warga masyarakat bersangkutan (Tjahjadi, 2004). 
Kelebihan yang dimiliki oleh agama Islam tidak dimiliki oleh agama-agama yang lain, bahwa Islam memberikan dasar yang lengkap bagi kebudayaan dan peradaban.

\section{1) Nilai Agama pada Bagian Pertama "Bercumbu dan Pengaduan Cinta"}

Sudah menjadi tradisi orang Arab ketika membuat syair pasti ia akan menyinggung kampung halamannya, terutama bagi Imam Bushiri yang merindukan kampung halamannya bersama dengan kekasihnya. Bahkan Tuhanpun menjadi saksi atas cintanya. Sepanjang ia hidup ia dicela, dan dengan rendah hati kepada semua orang. "lebih mudah mulut berucap ketika tidak berada dalam perkara". Banyak yang memberi nasihat tidak ada yang didengar karena orang yang mabuk cinta itu tidak bisa mendengar, ini sudah bukan masalah lagi, tetapi cinta itu tidak bisa hilang sekalipun aku sudah tua.

\section{2) Nilai Agama pada Bagian Kedua "Menjaga Hawa Nafsu"}

Al-Qur'an telah menegaskan bahwa jangan pernah mengikuti hawa nafsu hanya untuk keinginan semata, tapi kerusakannya begitu banyak. Nafsu adalah musuh terbesar seluruh umat manusia. Karena nafsu susah dikendalikan, maka dari itu Nabi Muhammad memperingatkan umatnya melalui sabdanya.

"dan hati yang hitam seperti cangkir yang terbalik, tidak mengenal yang ma'ruf dan tidak mengingkari yang munkar, kecuali yang sesuai dengan hawa nafsunya" (HR.Muslim)

Nafsu amarah itu datang dari keras kepala tidak mau menerima nasihat orang lain, jangan kau menuruti nafsu karena dengan menurutinya akan menjerumuskan ke lembah kehinaan.

\section{3) Nilai Agama pada Bagian Ketiga "Pujian Kepada Nabi Muhammad saw"}

Pada syair ini terdapat bahwa Imam Bushiri sedang memuji Sang Baginda akan keteguhan imannya, meski sudah ditawari oleh Allah dengan berbagai macam tawaran, tetapi ia tetap tidak tertarik. Meski itu tidak akan menghilangkan nilai kesuciannya, tapi tetap ia tidak tertarik. Sang baginda tidak tertarik dengan kemilauan dunia. Beliau memiliki keteguhan hati yang kuat, beliau senantiasa mengajak umatnya untuk beribadah kepada Allah swt., semata pepujian yang dilakukan ini tidaklah salah karena memang benar Sang baginda sungguh Nabi pembawa rahmat.

\section{4) Nilai Agama pada Bagian Keempat "Kelahiran Nabi Muhammad saw"}

Senin, 12 Rabi'ul Awal Tahun Gajah (570 M) Nabi Muhammad saw., dilahirkan di Mekah al-Mukarramah. Diantara tanda-tanda kelahiran sang Nabi, terjadi peristiwaperistiwa besar diantaranya adalah singgasana Kerajaan Kisra bergoyang hingga menimbulkan bunyi hingga menjatuhkan empat belas balkon, api sesembahan rakyat Persia padam, padahal api sesembahan itu belum pernah padam sejak seribu tahun sebelumnya, dan gereja-gereja disekitaran Buhairah amblas ke tanah dan kemudian runtuh.

\section{5) Nilai Agama pada Bagian Kelima "Mukjizat Nabi Muhammad saw"}

Pada kejadian mukjizat nabi, nabi dapat membelah bulan menjadi dua, karena para kafir Yahudi meminta bukti atas kerasulannya, lalu sang bagindapun menunjukkannya dengan cara membelah bulan menjadi dua, kemudian gumpalan awan yang melindungi Nabi ketika dalam perjalanan, kemudian ketika nabi bersembunyi dalam Gua Tsur bersama dengan sahabatnya Abu Bakar, dan semua para kafir (kaum Romawi) yang mengejarnya tak menemukan mereka dan bahkan tak percaya jika mereka bersembunyi di dalam gua.

\section{6) Nilai Agama pada Bagian Keenam "Kemuliaan Al-Qur'an"}

Al-Qur'an adalah Syifa' merupakan sisi penilaian yang bermakna dua sisi. Pertama, Al-Qur'an menunjukkan makna Syifa' sebagai petunjuk kepada makna umum, dan yang kedua, sebagai petunjuk kepada makna khusus. Makna pertama memberi gambaran tentang seluruh isi Al-Qur'an secara maknawi, surat-surat, ayat-ayat maupun huruf-hurufnya memiliki potensi penyembuh atau obat (Latif, 2014). Al-Qur'an adalah pengobat, membuka pintu atas semua permasalahan di muka bumi ini. Mendengarkan orang yang membaca AlQur'an dapat menyejukkan hati, menenangkan pikiran dan amarah, Al-Qur'an 
adalah obat sekaligus penakluk bagi penentangnya.

\section{7) Nilai Agama pada Bagian Ketujuh "Isra Mi'raj"}

Kabar gembira bagi umat muslim yang akan datang seorang Rasul yang taat kepada Allah swt., dan akan memperkokoh tiang agama. Peristiwa Isra Mi'raj adalah momen yang baik untuk memperkuat akidah umat Islam. Selain akidah, isra mi'raj juga mengandung pendidikan ibadah.

\section{8) Nilai Agama pada Bagian Kedelapan "Perjuangan Nabi Muhammad saw"}

Masa kejayaan umat Islam melalui perang besar, Islam itu benteng agama yang besar dan Al-Qur'an itu kitab suci penolong yang dapat menjatuhkan semua musuh. Perjuangan Nabi Muhammad saw., tidaklah mudah, beliau dengan penuh kesabaran mengajar para umat kepada kebenaran, meski harus berperang, meski harus saling menumpahkan darah, demi kajayaan umat Islam dikala itu sang Baginda tak segan-segan menghunuskan pedang. Nabi saw., memang sangat lembut nan baik hati. Tetapi jika ada yang menyakiti umat Islam disaat itu maka pasti beliau akan melindungi.

\section{9) Nilai Agama pada Bagian Kesembilan "Tawassul"}

Tawassul adalah berdoa kepada Allah swt., melalui suatu perantara, baik berupa amal, ataupun orang shalih yang posisinya dekat dengan Allah swt. Pada bagian ini Imam Bushiry berusaha untuk memuji Sang Baginda melalui salawat yang telah beliau buat, karena sang Baginda adalah kekasih Allah, dan dekat dengan Allah swt., jadi Imam Bushiry bersalawat kepadanya dengan tujuan mengadukan nasibnya, agar dapat disembuhkan oleh Allah swt., dan mendapatkan pertolongan serta keberkahanNya.

\section{0) Nilai Agama pada Bagian Kesepuluh "Bermunajat dan Meminta Hajat}

Pada bagian ini terlihat atas kepasrahan Imam Bushiri atas segala perbuatan yang ia telah lakukan, dan penderitaan yang ia alami. Ia pun kembali memuji Allah swt., melalui syair Burdahnya. Bermunajat agar dikabulkan permintaannya dengan penuh harap dan sungguh-sungguh agar benar-benar permohonannya diterima oleh Allah swt.

\section{c. Nilai Budaya}

Islam tidak hanya mengupayakan untuk ditegakkan di tengah-tengah masyarakat dalam artian pelaksanaan ajarannya, agama ini juga menjadi fondasi utama dalam pembentukan budaya, tradisi dan adat istiadat. Tradisi istana kerajaan dimasa lalu sarat dengan nilai-nilai Islami, sejak dari gelar yang digunakan, konsep kepemerintahan, tradisi seremonial istana (yang tidak membedakan antara tradisi keislaman dengan kerajaan), dan berbagai kebijakan keagamaan kerajaan, terutama pada abad ke 17 (Hadi, 2010). Bangsa Arabpun sudah lama berada di Gorontalo, hal ini dapat dibuktikan melalui foto mereka yang berada di Gorontalo pada tahun 1927, mereka datang melalui jalur perdagangan, hingga berdakwah dan masyarakat sekitarpun menyambut mereka dengan baik.

Sama halnya dengan tradisi Burdah ini, memang pada zaman dulu menjelang akad nikah tidak memakai acara apapun, namun seiring zaman berganti budaya-budaya yang lainpun mulai masuk dan mempengaruhi budaya lokal. Jika pada umumnya hanya berpesta dan berjoget (rahatan) disisi lain masyarakat kurang setuju akan hal itu. Pembaca Burdah mengatakan bahwa dari pada kita hanya berjoget tanpa ada manfaatnya, lebih baik bersalawat saja kepada Rasulullah, meminta syafaatnya, berdoa kepada Allah swt., atas kelancaran acara yang akan diselengarakan dan memohon agar rumah tangga dilindungi dari segala macam fitnah itu akan lebih baik (NA, 2019).

Tradisi ini sudah ada sejak dulu, kami mengambil manfaatnya agar mendapatkan berkah, dan anak-anak muda sekarangpun dilibatkan agar mereka dapat melestarikannya. Masyarakat Gorontalo yang ikut bergabung dalam majelis, juga menyukai Burdah, bahkan merekapun ikut melaksanakannya. Dari sinilah, suatu komunitas terbentuk, antar teman, saudara bahkan kerabat dimulai dari ajakan-ajakan yang sederhana, kemudian membentuk suatu komunitas yang menjadi suatu budaya dalam pelestarian khazanah Islam. Komunitas budaya tersebut diasumsikan sebagai bagian identitas diri bagi warga Gorontalo dalam sikap keberagaman yang didasari oleh sebuah pandangan budaya atau keyakinan tertentu 
yang disebut mapo 'otalo ibadah, (bahasa adat masyarakat Gorontalo) (Tohopi, 2012).

Ada 10 prinsip dasar falsafah adat masyarakat Gorontalo yang melekat untuk diamalkan dalam kehidupan sehari-hari, jika dilanggar mendapat sanksi sosial, terkecuali dan sekaligus mengalami degradasi kepercayaan di masyarakat, yakni: 1) Dila Mowali Mobijana (dilarang memfitnah), 2) Dila Mowali Matao (dilarang mencuri), 3) Dila Mowali Moyitohu Mongobuwa (dilarang main perempuan), 4) Dila Mowali Mohimbulo (dilarang berdusta), 5) Dila Mowali Mo Topu (dilarang berjudi), 6) Dila Mowali Mongilu Bohito (dilarang minum arak dan sejenisnya yang memabukkan), 7) Dila Mowali Mojalo to Tau (dilarang memarahi orang), 8) Dila Mowali Sombongiyolo (dilarang menyombongkan diri), 9) Dila Mowali Mopoyinggile to Tau (dilarang menyalahkan orang lain tanpa bukti tertentu), 10) Dila Mowali Mosilitas to Tau (dilarang membicarakan kekurangan/kejelekan orang lain) (Tohopi, 2012).

Dari kesepuluh adat di atas ada yang tertuang dalam naskah-naskah qasidah Burdah semua termasuk dalam naskah Burdah bagian ke dua, yaitu menjaga hawa nafsu dan terdapat beberapa bentuk larangan yang patut diketahui dan tidak boleh dilanggar.

\section{Kesimpulan}

Pembacaan Burdah bagi masyarakat etnis Arab Gorontalo dilaksanakan secara tradisional, dan dijunjung tinggi oleh etnis Arab. Burdah juga sudah menjadi meluas pelaksanaannya karena Burdah ini telah dilakukan juga oleh masyarakat Gorontalo sekalipun bukan berketurunan Arab tapi sebahagian juga mereka sudah membuadayakannya. Hal ini selain menjadi hiburan pada acara-acara tertentu, ia juga mengandung doa. Sehingga hal ini terterima dengan baik. Dilihat dari sisi manfaatnya sangat bermanfaat ketimbang menyanyi dengan lagu-lagu yang dapat mengundang orang bergoyang dan berjoged. Qasidah Burdah diterima dengan baik oleh warga Gorontalo karena masih bersandarkan pada sendi-sendi syariat dan adat disandarkan pada kitab Allah swt., yakni Al-Qur'an, sehingga Burdah dapat dilaksanakan pada pembacaan di majelis-majelis hingga acara pernikahan yang sampai saat ini masih dilakukan oleh masyarakat Arab Gorontalo. Pandangan masyarakat Gorontalo khususnya etnis Arab memandang bahwa pemnbacaan Burdah seperti ini harus dipelihara dan dilestarikan jangan sampai punah karena secara tradisional adalah salah satu ciri adat masyarakat Gorontalo. Nilai edukatif yang terdapat dalam tradisi pembacaan Burdah di Gorontalo mempunyai nilai-nilai pendidikan sosial, agama, dan budaya.

\section{Daftar Pustaka}

Abdul Wahhab Khallaf. (1994). Ilmu Ushul Fiqh. Semarang: Dina Utama.

Adib, M. (2009). Burdah: Antara Kasidah, Mistis dan Sejarah. Pustaka Pesantren.

Aini, N. (2019). Internalisasi Nilai-Nilai Pendidikan Agama Islam pada Kegiatan Ekstrakurikuler Rohaniah Islam Dalam Membina Karakter Peserta Didik di Sma Negeri 1 Air Putih Kecamatan Air Putih Kabupaten Batu Bara. ANSIRU PAI: Pengembangan Profesi Guru Pendidikan Agama Islam, 3(2), 4961.

Aisah, S. (2017). Nilai-Nilai Sosial yang Terkandung dalam Cerita Rakyat "Ence Sulaiman" pada Masyarakat Tomia. JURNAL HUMANIKA, 3(15). Diambil dari http://ojs.uho.ac.id/index.php/HUMA NIKA/article/view/607

Arifin, A. S. (2018). Pemaknaan Teks Syair Qashidah Burdah Karya Imam Syarifuddin Muhammad Bushiry (Kajian Semiotika Michael Riffaterre) (Other, Universitas Sebelas Maret). Universitas Sebelas Maret. Diambil dari https://eprints.uns.ac.id/40524/

As'adi, M. H. (2020). Tradisi Suku Gorontalo Sebagai Media Komunikasi Tradisional Pada Masyarakat Titidu dan Manfaatnya Bagi Pembangunan Daerah. Kalijaga Journal of Communication, 2(1), 35-52. https://doi.org/10.14421/kjc.\%x.2020 
As-Sa'di, S. A. bin N. (2012). Tafsir AlQur'an. Jakarta: Darul Haq.

Bakari, I. A. R. (2014). Studi Kritis Terhadap Pemikiran Al-Busairi Dalam Kasidah Al-Burdah (Masters, Universitas Islam Negeri Alauddin Makassar). Universitas Islam Negeri Alauddin Makassar. Diambil dari http://repositori.uinalauddin.ac.id/2315/

Botutihe, H. M., \& Daulima, P. (2003). Tata Upacara Adat Gorontalo: Dari Upacara Adat Kelahiran, Perkawinan, Penyambutan Tamu, Penobatan dan Pemberian Gelar Adat Sampai Upacara Adat Pemakaman. Gorontalo.

Darwis, \& Mas'ud, H. (2017). Kesehatan Masyarakat dalam Perspektif Sosioantropologi. SAH MEDIA.

Djamal, S. M. (2017). Pelaksanaan Nilai-nilai Ajaran Islam Dalam Kehidupan Masyarakat Di Desa Garuntungan Kecamatan Kindang Kabupaten Bulukumba. Jurnal Adabiyah, 17(2), 161-179.

https://doi.org/10.24252/JAd.v17i1i2 a5

Fadhilla. (2013). Tahapan Hubungan Menuju Pernikahan (Commited Romantic Relationship) pada Etnis Arab di Kampung Arab Ampel, Surabaya (Skripsi, UNIVERSITAS AIRLANGGA). UNIVERSITAS AIRLANGGA. Diambil dari http://lib.unair.ac.id

Fahriah, A. (2012). Tema dan Amanat Dalam Qashidah Burdah Karya Imam AlBushairi yang Mengandung AtThibaq (Tinjauan Ilmu Badi'). Students e-Journal, 1(1), 1.

Fajrie, M. (2016). Budaya Masyarakat Pesisir Wedung Jawa Tengah: Melihat Gaya Komunikasi dan Tradisi Pesisiran. Penerbit Mangku Bumi.

Faqieh, M. I. (2010). Fatwa dan Canda Gus Dur. Penerbit Buku Kompas.
Fattaah, A. (2018). Tradisi Perkawinan Etnis Arab kota Malang: Studi Pada Masyarakat Etnis Arab di Kelurahan Kauman Kecamatan Klojen Kota Malang (Undergraduate, Universitas Islam Negeri Maulana Malik Ibrahim). Universitas Islam Negeri Maulana Malik Ibrahim. Diambil dari http://etheses.uinmalang.ac.id/14024/

Fitriyah, A. (2016). Akhlak Dalam Kasidah Burdah (Studi Pembacaan Burdah di Pondok Pesantren Nurul Jadid Paiton, Probolinggo). Diambil dari http://repository.unej.ac.id/handle/12 $3456789 / 78237$

Hadi, A. (2010). Aceh: Sejarah, Budaya, dan Tradisi. Yayasan Pustaka Obor Indonesia.

Hasanah, U. (2017). Nilai Moral Dalam SĀQ Al-BAMBŪ Karya SA'ŪD ALSAN'ŪSĪ. Adabiyyāt: Jurnal Bahasa dan Sastra, 1(1), 112-138. https://doi.org/10.14421/ajbs.2017.01 106

Imelda, A. (2017). Implementasi Pendidikan Nilai Dalam Pendidikan Agama Islam. Al-Tadzkiyyah: Jurnal Pendidikan Islam, 8(2), 227-247. https://doi.org/10.24042/atjpi.v8i2.21 28

Latif, U. (2014). Al-Qur'an Sebagai Sumber Rahmad dan Obat Penawar (Syifa') Bagi Manusia. Jurnal Al-Bayan: Media Kajian Dan Pengembangan Ilmu Dakwah, 20(2). https://doi.org/10.22373/albayan.v20 i30.125

Mahlan. (2015). Nilai-Nilai Spiritual Sufistik Qashidah Burdah Dalam Meningkatkan Religiusitas (Studi Fenomena Di Pondok Pesantren Darussalam Martapura) (Masters, Pasca Sarjana). Pasca Sarjana. Diambil dari https://idr.uinantasari.ac.id/2344/

Mansoer, M. T. (2006). Sajak Sajak Burdah Imam Muhammad Al-Bushiri. ADAB 
Vol. 16, No. 02, Desember 2020, p. 149-162

PRESS. (Yogyakarta). Diambil dari //lib.iainpurwokerto.ac.id/index.php? $\mathrm{p}=$ show_detail\&id=85042\&keyword $\mathrm{S}=$

Miftahul. (2015). Adat Turun Tanah Bagi Suku Jawa Di Kota Palangka Raya Ditinjau Dari Prespektif Islam. Jurnal Studi Agama dan Masyarakat, 11(2), 191-208. https://doi.org/10.23971/jsam.v11i2. 437

Mustajab. (2015). Masa Depan Pesantren: Telaah atas Model Kepemimpinan dan Manajemen Pesantren Salaf. Lkis Pelangi Aksara.

Muzakki, A. (2006). Kesusastraan Arab: Pengantar Teori dan Terapan. ArRuzz Media.

NA. (2019). Wawancara.

Nabilah, J. (2018, November 22). Kasidah Burdah: Syair Cinta Untuk Sang Rasul. Diambil 23 Desember 2020, dari BincangSyariah | Portal Islam Rahmatan lil Alamin website: https://bincangsyariah.com/khazanah /mengenal-kasidah-Burdah/

Natalia, D., Tarantang, J., \& Astiti, N. N. A. (2020). Makna Manuhir Dalam Kehidupan Masyarakat Dayak Ngaju di Kota Palangka Raya. Jurnal Studi Agama dan Masyarakat, 16(1), 2434.

https://doi.org/10.23971/jsam.v16i1. 2077

Nihaya, U. (2014). Konsep Seni Qasidah Burdah Imam Al Bushiri Sebagai Alternatif Menumbuhkan Kesehatan Mental. Jurnal Ilmu Dakwah Walisongo, 34(2), 295-308. https://doi.org/10.21580/jid.v34.2.48 8

Nihayah, U. (2015a). Qasidah Burdah Imam Al-Bushiri; Model Alternatif Dakwah

Pesantren. An-Nida: Jurnal Komunikasi Islam, 7(1). https://doi.org/10.34001/an.v7i1.289

Nihayah, U. (2015b). Qasidah Burdah Imam

Al-Bushiri; Model Alternatif Dakwah
Pesantren. An-Nida: Jurnal

Komunikasi Islam, 7(1). https://doi.org/10.34001/an.v7i1.289

NUA. (2019). Wawancara.

Oktaviyanti, I., Sutarto, J., \& Atmaja, H. T. (2016). Implementasi Nilai-Nilai Sosial Dalam Membentuk Perilaku Sosial Siswa SD. Journal of Primary Education, 5(2), 113-119. https://doi.org/10.15294/jpe.v5i2.129 01

Rahman, M. G. (2012). Tradisi Molonthalo di Gorontalo. Al-Ulum, 12(2), 437-456.

Ramin, M. M. (2018). Pergeseran Makna dan Tujuan Pembacaan Burdah di Desa Jaddung, Pragaan, Sumenep. Living Islam: Journal of Islamic Discourses, 1(2), 299-316. https://doi.org/10.14421/lijid.v1i2.17 32

Rosalinda. (2013). Tradisi Baca Burdah dan Pengalaman Keagamaan Masyarakat Desa Setiris Muaro Jambi. Kontekstualita: Jurnal Penelitian Sosial Keagamaan, 28(2), 170-181.

Saputra, E. W. (2017). Makna Dupa dalam Tradisi Assuro Ammaca di Desa Bone Kecamatan Bajeng Kabupaten Gowa (Diploma, Universitas Islam Negeri Alauddin Makassar). Universitas Islam Negeri Alauddin Makassar. Diambil dari http://repositori.uinalauddin.ac.id/8979/

Sholikhin, M. (2010). Ritual dan Tradisi Islam Jawa: Ritual-ritual dan Tradisi-tradisi Tentang Kehamilan, Kelahiran, Pernikahan, dan Kematian Dalam Kehidupan Seharihari Masyarakat Islam Jawa. Yogyakarta: Penerbit Narasi.

Sucipto. (2015). 'Urf Sebagai Metode Dan Sumber Penemuan Hukum Islam. Asas: Jurnal Hukum dan Ekonomi Islam, $\quad 7(1), \quad 135023$. https://doi.org/10.24042/asas.v7i1.13 76 
Tantowi, A. (2009). Pendidikan Islam di era transformasi global. Pustaka Rizki Putra.

Tjahjadi, S. P. L. (2004). Petualangan Intelektual Konfrontasi Dengan Para Filsuf Dari Zaman Yunani Hingga Zaman Modern. Yogyakarta: Kanisius. (Yogyakarta). Diambil dari //munas.kemdikbud.go.id/katalog/ind ex.php?p=show_detail\&id=1418

Tohopi, R. (2012). Tradisi Perayaan Isra' Mi'raj Dalam Budaya Islam Lokal Masyarakat Gorontalo. ElHARAKAH (TERAKREDITASI),
14(1),

$135-155$.

https://doi.org/10.18860/el.v0i0.2192

Yani, H. A. (2006). 160 Materi Dakwah Pilihan. Jakarta: Gema Insani.

ZAB. (2019). Wawancara.

Zubaedi. (2012). Isu-isu Baru dalam Diskursus Filsafat Pendidikan Islam dan Kapita Selekta Pendidiokan Islam (No. 1; Vol. 1). Pustaka Pelajar. Diambil dari http://repository.iainbengkulu.ac.id/4 431/ 